місчевого самоврядувания. 2015. № 2. URL : http://nbuv.gov.ua/UJRN/Ttpdu_2015_2_20 (дата звернення 09.11.2018)

11. Щука Г.П. Теоретичні аспекти формування ціннісних орієнтацій майбутніх фахівців сфери туризму у ВНЗ. Карпатський край. № 1-2 (6-7). 2015. С. 252-256.

\title{
References
}

1. Bilova Yu.A. Poniattia ta struktura pidpryiemnytskoi kompetentnosti maibutnikh fakhivtsiv ekonomichnoho profiliu. Onovlennia zmistu, form ta metodiv navchannia i vykhovannia v zakladakh osvity. 2013. Vyp. 7. S. 15-17.

2. Bohdan N. M., Sukhorukova O. P. Doslidzhennia ryzykiv u turyzmi. Biznes-inform. 2016. № 10. S.206-211.

3. Varnalii Z. S. Osnovy pidpryiemnytstva : navch. posib. Kyiv: "Znannia-Pres", 2006. $350 \mathrm{~s}$.

4. Zavadskyi Y.S., Osovska T.V., Yushkevych O.O. Ekonomichnyi slovnyk. Kyiv : Kondor, 2006. 355 s.

5. Zeer E.F. Psykholohyia professyi : uchebnoe posobye dlia studentov vuzov. 2-e yzd., pererab., dop. Moskva : Akademycheskyi Proekt; Ekaterynburh : Delovaia knyha, 2003. 149 s.

6. Matukova H. I. Pedahohichni umovy rozvytku $v$ studentiv ekonomichnykh spetsialnostei kompetentnosti do pidpryiemnytskoi diialnosti. Profesiina osvita : problemy i perspektyvy. 2015. Vyp. 8. S. 35-42. URL : http://nbuv.gov.ua/UJRN/Profos_2015_8_8 (data zvernennia 08.11.2018)

7. Pachkovskyi Yu.F. Pidpryiemnytstvo yak predmet sotsiopsykholohichnoho doslidzhennia (diialnisno-povedinkovyi aspekt) : avtoref. dys. na zdobuttia nauk. stupenia d-ra sotsiol. nauk : 22.00.04. Natsionalna akademiia nauk Ukrainy. Instytut sotsiolohii. Kyiv, 2004. $36 \mathrm{~s}$

8. Pryimuk O.O. Psykholohichni umovy formuvannia profesiinykh yakostei zdobuvachiv vyshchoi osvity : dys. na zdobuttia nauk. stupenia kand. psykh. nauk : 19.00.10. Kyivskyi natsionalnyi torhovelno-ekonomichnyi universytet. Kyiv, 2017. 342 s.

9. Pro vyshchu osvitu : Zakon Ukrainy vid 1.07.2014 № 1556-VII. URL https://zakon.rada.gov.ua/laws/show/1556-18 (data zvernennia 12.12.2017)

10. Tkach V., Kamushkov O., Zakharova S. Rozvytok pidpryiemnytstva u sferi turyzmu: derzhavnyi ta ekonomichnyi mekhanizm. Teoriia ta praktyka derzhavnoho upravlinnia i mistsevoho samovriaduvannia. 2015. № 2. URL : http://nbuv.gov.ua/UJRN/Ttpdu_2015_2_20 (data zvernennia 09.11.2018)

11. Shchuka H.P. Teoretychni aspekty formuvannia tsinnisnykh oriientatsii maibutnikh fakhivtsiv sfery turyzmu u VNZ. Karpatskyi krai. № 1-2 (6-7). 2015. S. 252-256.

Одержано статтю: 01.08.2019

Прийнято до друку: 15.08.2019

УДК 378.67.015.31:084

DOI: $10.15330 /$ esu. $16.92-97$

\author{
Тетяна Козак, \\ кандидат педагогічних наук, доцент, \\ Національний педагогічний університет імені \\ М.П.Драгоманова (м. Київ, Україна) \\ Tetiana Kozak, \\ Candidate of pedagogical sciences $(\mathrm{PhD})$, Associate \\ Professor, National Pedagogical Drahomanov \\ University (Kyiv, Ukraine) \\ tanyaosmak27@gmail.com
}

\section{ФОРМУВАННЯ ХУДОЖНЬО-ЕСТЕТИЧНОЇ КОМПЕТЕНТНОСТІ СТУДЕНТІВ У ВИЩИХ ЗАКЛАДАХ ОСВІТИ УКРӒ̈НИ}

\section{FORMING OF ARTISTIC AND AESTHETIC COMPETENCE OF STUDENTS IN HIGHER EDUCATIONAL INSTITUTIONS OF UKRAINE}

У статті обтрунтовано систему критеріїв, показників та рівнів вимірювання художньо-естетичної компетентності студентів як результату фахової підготовки 6 університетах. Охарактеризовано поняття “художньо-естетична компетентність", ї 
формування у студентів, визначено критерії художньо-естетичної компетентності студентів (особистісний, навчальний, творчий), подано їх характеристику. У висновках зазиачено, ио формувания, розвиток художньо-естетичної компетентності у студентів можливі після засвоєння теоретичної бази знань, практичної діяльності та саморозвитку, це $\epsilon$ основною передумовою становлення його як особистості. Художньо-естетична компетентність для студента - це майже основна передумова становления його як особистості. Майбутній фахівечь з образотворчого мистечтва має бути зорієнтована на формування і розвиток здатності до сприйняття дійсності, мистецтва та культури, творчої художньої індивідуальності та розвитку практичних вмінь - необхідних чинників кваліфікованого спечіаліста.

Ключові слова: художньо-естетична компетентність, живопис, критерій, компетентність, художн компетентність, мистецька освіта.

The article substantiates the system of criteria, indicators and levels of measurement of artistic and aesthetic competence of students as a result of professional training in universities. The concept of "artistic and aesthetic competence", its formation in students, criteria of artistic and aesthetic competence of students (personal, educational, creative) are defined, their characteristics are given. Training of specialists in fine art in the system of institutions of higher education is a very complicated process that requires contimuous improvement and deepening of the theoretical knowledge base, the search for and implementation of new methods and techniques in the educational process. Mastering various painting techniques is necessary for the professional formation of student youth who have chosen the artistic direction of education. Artistic and aesthetic competence for a student is almost the basic precondition for becoming him as a person. However, for this purpose, both theoretical knowledge of painting and learned skills in possession of techniques and materials should be generalized.

The conclusions state that the formation, development of artistic and aesthetic competence among students is possible after the assimilation of the theoretical basis of knowledge, practical activity and self-development, this is the main prerequisite for becoming him as a person. Artistic and aesthetic competence for a student is almost the basic precondition for becoming him as a person. The future specialist in fine art should be oriented towards the formation and development of the ability to perceive reality, art and culture, creative artistic personality and the development of practical skills - the necessary factors of a qualified specialist.

Key words: artistic and aesthetic competence, painting, criterion, competence, artistic competence, artistic education.

Постановка проблеми. Сучасна освітня політика в Україні торкається проблеми гуманізації освіти, в основу якої покладено забезпечення пріоритетності загальнолюдських та поліхудожніх цінностей, створення умов для формування художньо-естетичної компетентності особистості.

На забезпечення цього процесу націлені ідеї та положення, викладені в державних нормативно-правових документах України з проблем освіти: в законах України "Про освіту”, “Про вищу освіту”, Державній національній програмі “Освіта” (Україна XXI століття), Програмі “Вчитель”, Концепції виховання дітей та молоді в національній системі освіти, Концепщії художньо-естетичного виховання учнів у загальноосвітніх навчальних закладах, Національній доктрині розвитку освіти в Україні, Національній стратегії розвитку освіти в Україні на 2012 - 2021 рр. та ін.

Мета статті. Обгрунтувати систему критеріїв, показників та рівнів вимірювання художньо-естетичної компетентності студентів як результату фахової підготовки в університетах. 
Виклад основного матеріалу дослідження. Мистецька освіта в Україні, зокрема живопис, має великий вплив на становлення і розвиток художньо-естетичної компетентності студентів.

Головним компонентом естетико-виховної системи студентства $є$ навчальна діяльність, адже саме під час систематичного викладання предметів художньоестетичного циклу створюються умови для розвитку творчого потенціалу та формування художньо-естетичних компетентностей. Цілісний педагогічний процес у закладі вищої освіти має великі потенційні можливості художньо-естетичного виховання студентської молоді і забезпечує реалізацію духовно-культурного змісту цінностей освіти і виховання. Художньо-естетичне виховання виконує функцію гармонізації освітнього процесу, створення особистісно-значущої ситуації художньо-естетичного розвитку студентської молоді [2, с. 15].

Поняття "компетентність" (лат. comhetentia - comhetentia - коло питань, в яких людина добре розуміється) вчені розглядають як інтегральну характеристику, яка визначає готовність і здатність на високому професійному рівні виконувати фахові обов'язки відповідно до сучасних теоретичних та практичних надбань, професійного й життєвого досвіду. В основі поняття компетентності лежить ідея виховання компетентного фахівця, який має не лише необхідні знання, професіоналізм, високі моральні якості, а й вміє діяти адекватно у відповідних ситуаціях, застосовуючи ці знання, беручи на себе відповідальність за певну діяльність [4, с. 3]. Компетентності, що формуються у процесі загальної мистецької освіти, умовно поділяються (за Л. Масол) на особистісні, функијіональні, соиіальні.

Згідно 3 класифікацією серед функціональних компетентностей можна виокремити предметні або мистецькі, пов'язані 3 певною галуззю мистецької діяльності (в нашому випадку - живопис); міжпредметні, що поєднують два або більше мистецтв чи предметів єдиною педагогічною метою; метапредметні, до яких належать інформаційно-пізнавальні, саморегулятивні (що проявляються в здатності до самоосвіти, самовиховання, самореалізаціі), а також креативні. Окрему групу становлять соціальні компетентності, які формуються під час колективної діяльності (у тому числі і художньої), до яких зараховуємо художньо-комунікативні, художньокооперативні (соціально-практичні).

Художньо-естетична компетентність - це обізнаність у галузі мистецтва, прагнення та здатність реалізувати на практиці свій художньо-естетичний потенціал для одержання власного неповторного результату творчої діяльності, де під художньо-естетичним потенціалом розуміється: певний обсяг культурно-історичних та художньо-естетичних знань; уміння та навички художньо-естетичного сприймання, аналізу й інтерпретації творів мистецтва відповідно до авторського задуму, розуміння єдності форми та змісту; готовність особистості до художньотворчої реалізації, самостійного пізнання мистецтва, естетичної оцінці творів мистецтва [2, с. 72].

За Л. Масол, художня компетентність - здатність керуватися набутими художніми знаннями та вміннями, готовність використовувати отриманий досвід у самостійній діяльності згідно з універсальними загальнолюдськими естетичними цінностями та власними духовно світоглядними позиціями.

Науковець А. Гогоберідзе вважає, що художня компетентність - здатність самостійно вирішувати завдання, пов'язані 3 художнім сприйняттям та інтерпретацією творів мистецтва різних видів i жанрів та мистецтвом у різноманітних проявах художньої діяльності. 
У наукових дослідженнях виділяють критерії сформованості художньоестетичної компетентності: особистісний, навчальний і творчий. Так, особистісний це дослідження особистісних характеристик студентів, що впливають на формування художньо-естетичної компетентності. Основні їх показники: здатність до міжкультурної й міжособистісної інтеграції; особливості сприйняття та мислення; позитивна спрямованість особистості на навчання й професійну художньо-естетичну діяльність; свідомість емоційних реакції, їх просоціальний характер; гнучкість і самостійність асоціативного мислення та творчої діяльності; широта свідомості, контрольованість пізнавальних процесів.

Навчальний - оцінювання навчальних досягнень майбутніх фахівців мистецького профілю як відображення художньо-естетичних i фахових знань та вмінь. Основні показники цього критерію - це міцність та глибина знань із дисциплін соціально-гуманітарного, природничо-наукового, професійно-практичного спрямування; обізнаність із методами, формами та технологіями художньо-естетичної діяльності.

Творчий - дослідження суб'єктного характеру художньо-естетичної діяльності в середовищі коледжу культури і мистецтв. Показниками виступають володіння проектною, конструкторською, технічною, технологічною, організаційно-контрольною та соціально-освітньою компетенціями; виявлення розвинутої культури творчої діяльності; готовність до реалізації художньо-естетичної компетентності у майбутній фаховій діяльності [7].

Розглянемо понятійний апарат терміна “формування”. Так, “формування”, за Р. Немовим, є процесом розвитку та становлення особистості під впливом зовнішніх дій виховання, навчання, соціального середовища; цілеспрямований розвиток особистості чи яких-небудь іiі сторін, якостей під впливом виховання та навчання; процес становлення людини як суб'єкта та об'єкта суспільних відносин [6].

Н. Мойсеюк зазначає, що “формування - це процес становлення людини як соціальної істоти під впливом усіх без винятку факторів - соціальних, економічних, ідеологічних, психологічних та ін." [1, с. 365]. Поділяючи думку В. Сластьоніна [5] щодо поняття "формування", відзначимо, що це є процес оволодіння особистості сукупністю стійких властивостей та якостей.

Компетентність у художньо-естетичному напрямі полягає у перебуванні у безперервному пошуковому стані чогось нового, цікавого, гарного, гармонійного. Особливості художньо-естетичної компетентності студента зумовлені художньою майстерністю, тобто, оволодінням мовою образотворчого мистецтва, його різними техніками і матеріалами, без чого у педагогічній діяльності неможливо досягти реалізації якісних результатів навчання.

Підготовка спеціалістів з образотворчого мистецтва у системі закладів вищої освіти - складний процес, який вимагає постійного вдосконалення і поглиблення теоретичної бази знань, пошуку та втілення нових методів і прийомів у навчальний процес. Однією 3 найважливіших дисциплін художнього циклу у підготовці майбутніх фахівців 3 образотворчого мистецтва $€$ живопис. Оволодіння різними живописними техніками необхідне для професійного становлення студентської молоді, які обрали мистецький напрям освіти. Художньо-естетична компетентність для студента - це майже основна передумова становлення його як особистості. Однак для цього повинні бути узагальнено як теоретичні знання 3 живопису, так i відпрацьовані навички володіння техніками та матеріалами. 
Так, при ознайомленні з технічними можливостями акварельних, олійних, акрилових, гуашевих фарб на практичних заняттях у вищих закладах освіти студенти відпрацьовують власну манеру письма різними матеріалами, адже для кожної фарби існує свій методологічний підхід і техніка. За допомогою виразних засобів живопису досягається розвиток, а саме: емоційно-образної форми мислення; естетичного сприйняття творів мистецтва; художнього бачення; вмінь та навичок володіння різними техніками та матеріалами [7].

Щоб студенти мали приклад кращого, професійного, індивідуального, всього того, що виконано після засвоєння знань з живопису, малюнку, кольорознавства, на заняттях із цього предмета для активної діяльності і стимулювання бажано демонструвати наочний матеріал (репродукції робіт різних майстрів та студентівпопередників). Адже, як зауважує М. Ростовцев, “технічні навички й секрети майстерності приходять до художника не самі по собі, а внаслідок тривалої наполегливої роботи. Свобода i віртуозність володіння мовою мистецтва дає можливість художнику цілком віддаватися творчості, легко реалізовувати творчі задуми. Художник, який слабко володіс зображальною технікою, стає скутим i не може повною мірою виразити свої задуми" [3, с. 184].

Формування та подальший розвиток художньо-естетичної компетентності у студентів можливі тільки після засвоєння теоретичної бази знань із дисципліни “Живопис", практичної діяльності та саморозвитку. Розвиток власних естетичних поглядів студент може отримати, наприклад, під час переглядів художніх фільмів мистецького напряму, різних майстер-класів художників, як з України, так i всесвітньовідомих майстрів різних країн, відвідування мистецьких семінарів, концертів, зустрічей із відомими художниками, відвідування виставок як місцевого значення, так і в перегляді праць учасників із всеукраїнських виставок, у перегляді робіт художників в електронних художніх галереях, адже це стало доступнішим у час інформаційних технологій.

Висновки. Художньо-естетична компетентність для студента - це майже основна передумова становлення його як особистості. Однак для цього повинні узагальнюватися як теоретичні знання з живопису, так і відпрацьовані навички володіння техніками та матеріалами. Підготовка майбутнього фахівця 3 образотворчого мистецтва має бути зорієнтована на формування і розвиток здатності до сприйняття дійсності, мистецтва та культури, творчої художньої індивідуальності та розвитку практичних вмінь - необхідних чинників кваліфікованого спеціаліста.

\section{Література}

1. Мойсеюк Н. Є. Педагогіка. Навчальний посібник // Н. Є. Мойсеюк. - К. : ВАТ КДНК. - $2001-$ $608 \mathrm{c}$

2. Пастухова Ю. А. Художньо-естетичне виховання студентської молоді в цілісному педагогічному процесі університету / Юлія Анатоліївна Пастухова: Автореф. Дис. канд. наук: 13.00.07. - теорія та методика виховання. - Луганськ, 2009. - 20 с.

3. Ростовцев Н. Н. Очерки по истории методов преподавания рисунка. - М., 1983. - с. 184.

4. Сотська Г. І. Естетично-професійна компетентність майбутнього вчителя образотворчого мистецтва Режим доступу : http://lib.iitta.gov.ua

5. Сластенин В. О. Педагогика / В. О. Сластенин. - М. : Просвещение. - 1987. - 362 с.

6. Немов Р. С. Психология : учебное пособие / Р. С. Немов. - М. : Просвещение. $-1990 .-301$ с.

7. Електронний ресурс. Режим доступу - file:///C:/Users $\%$ D0\%A2\%D0\%B0\%D0\%BD \%D1\%8F /Downloads/Vznu_ped_2015_1_21.pdf

\section{References}

1. Moiseiuk N. Ye. Pedahohika. Navchalnyi posibnyk // N.Ie. Moiseiuk. - K. : VAT KDNK. - $2001-$ $608 \mathrm{~s}$. 
2. Pastukhova Yu. A. Khudozhno-estetychne vykhovannia studentskoi molodi $\mathrm{v}$ tsilisnomu pedahohichnomu protsesi universytetu / Yuliia Anatoliivna Pastukhova: Avtoref. Dys. kand. nauk: 13.00.07. - teoriia ta metodyka vykhovannia. - Luhansk, 2009. $-20 \mathrm{~s}$.

3. Rostovtsev N. N. Ocherky po ystoryy metodov prepodavanyia rysunka. - M., 1983. - s.184.

4. Sotska H. I. Estetychno-profesiina kompetentnist maibutnoho vchytelia obrazotvorchoho mystetstva Rezhym dostupu : http:/ /lib.iitta.gov.ua

5. Slastenyn V. O. Pedahohyka / V. O. Slastenyn. - M.: Prosveshchenye. - 1987. -362 s.

6. Nemov R. S. Psykholohyia : uchebnoe posobye / R. S. Nemov. - M. : Prosveshchenye. $-1990 .-301 \mathrm{~s}$.

7. Elektronnyi resurs. Rezhym dostupu - file://C:/Users $/ \% \mathrm{D} 0 \% \mathrm{~A} 2 \% \mathrm{D} 0 \% \mathrm{~B} 0 \% \mathrm{D} 0 \% \mathrm{BD} \% \mathrm{D} 1 \% 8 \mathrm{~F} /$ Downloads/Vznu_ped_2015_1_21.pdf

Одержано статтю: 12.06.2019

Прийнято до друку: 26.06.2019

УДК 371.211 .24

DOI: $10.15330 /$ esu. 16.97-102

\section{Яна Лацівська,} аспірантка, Східноєвропейський національний університет імені Лесі Українки (м. Луцьк, Україна) Yana Laschivska,

Post-graduate student, Eastern European National University Lesya Ukrainka (Lutsk, Ukraine) lashchivskayana@ukr.net

\section{ПРОФЕСІЙНА МАЙСТЕРНІСТЬ ЯК ОСНОВНИЙ КОМПОНЕНТ ПЕДАГОГІЧНОӤ КУЛЬТУРИ}

\section{PROFESSIONAL MASTERNESS AS THE BASIC COMPONENT OF PEDAGOGICAL CULTURE}

У статті розкриваються питання професійної майстерності майбутніх магістрів музичного мистечтва. Підкреслено, що професійно-педагогічна майстерність як наукова проблема грунтовно досліджується сучасними психологами, філософами, педагогами на теоретичному, експериментально-дослідному рівнях (обтрунтування сутності, складників майстерності, визначення й експериментальна перевірка умов, засобів ї формування точи).

Так, маючи глибокі сочіальні й історичні корені, проблема професійної майстерності майбутнього магістра музичного мистечтва, майбутнього педагога залииалась надзвичайно актуальною. Як відомо, витоки пї полягають в ідеях давнього риторичного мистецтва і безпосередній ораторській діяльності. Необхідним складником професійной майстерності майбутнього магістра музичного мистечтва вчені досліджуваного періоду називали спечіальну, фундаментальну фахову підготовку.

Цілком очевидно, що вимоги до сучасного магістра музичного мистечтва повинні відповідати потребам сьогодення і передбачати: високий професіоналізм в обраній сфері; інновачійний характер мислення і готовність до змін. Разом з тим висококваліфікований магістр музичного мистечтва повинен володіти основними етичними нормами та правилами поведінки у ділових відносинах. Водночас необхідно розвивати і сочіальнопсихологічні навички діяльності майбутнього магістра музичного мистечтва, які мають базуватися на знанні засад формувания організачійної культури, реалізачії принципів розвитку сочіальних відносин, традииій, звичайв. Адже духовність, культура, інтелігентність с невід'смними складовими професіоналізму майбутнього магістра, особливо коли його діяльність пов 'язана з людьми. Професійна майстерність майбутнього магістра музичного мистеитва має формуватись у процесі здійснення методичного забезпечення навчального прочесу в закладах освіти різного типу. 